\title{
Core sediment biogeochemistry in specific zones of Cochin Estuarine System (CES)
}

\author{
P S Akhil, Manju P Nair and C H Sujatha* \\ Department of Chemical Oceanography, School of Marine Sciences, CUSAT, Cochin 16, Kerala, India. \\ ${ }^{*}$ Corresponding author. e-mail: drchsujatha@yahoo.co.in
}

Geochemical composition is a set of data for predicting the climatic condition existing in an ecosystem. Both the surficial and core sediment geochemistry are helpful in monitoring, assessing and evaluating the marine environment. The aim of the research work is to assess the relationship between the biogeochemical constituents in the Cochin Estuarine System (CES), their modifications after a long period of anoxia and also to identify the various processes which control the sediment composition in this region, through a multivariate statistical approach. Therefore the study of present core sediment geochemistry has a critical role in unraveling the benchmark of their characterization. Sediment cores from four prominent zones of CES were examined for various biogeochemical aspects. The results have served as rejuvenating records for the prediction of core sediment status prevailing in the CES.

\section{Introduction}

Estuaries are commonly described as semi-enclosed bodies of water, situated at the interface between land and ocean, where seawater is measurably diluted by the inflow of freshwater (Hobbie 2000). These dynamic ecosystems have the highest biotic diversity and production in the world. Recent estimates indicate that $61 \%$ of the world population lives along the coastal margin (Alongi 1998). Impacts of demographic changes in human populations have clearly had detrimental effects on the overall biogeochemical cycling in estuaries. Nutrient enrichment is perhaps the most widespread problem in estuaries around the world (Howarth et al. 2000, 2002). Understanding the biogeochemical and physical processes that play an important role in regulating the chemistry and biology of estuaries is fundamental to evaluate the complex management issues (Hedges and Kiel 1995; Middelburg et al. 1996; Bianchi et al. 1999a; Hobbie 2000). Biogeochemical cycles involve the interaction of biological, chemical as well as geological processes that determine sources, sinks, and fluxes of elements through different reservoirs within the ecosystems.

Cochin Estuary, one of the largest tropical estuaries of India is facing gross pollution problems following the release of untreated effluents from industries and domestic sectors. The major polluting industries in the region include fertilizer plant, oil refinery, rare earth processing plant, minerals and rutiles plant, zinc smelter plant, insecticide manufacturing unit and organic chemical plant. Reclamations over the past several decades have resulted in considerable shrinkage $(40 \%)$ of the Cochin Estuary (Gopalan et al. 1983). Further, construction of hydraulic barriers on the northern and southern limbs of the estuary to prevent saline intrusion into the upstream agricultural fields has imposed severe flow restrictions and increased sedimentation in the estuary (Menon et al. 2000). The developmental activities in and around Cochin Backwater System have added to the

Keywords. Cochin Estuarine System; core sediment; biogeochemical constituents. 
complexities and environmental dilemmas in this coastal niche. The rapid growth in the region accompanied by very high population growth, housing shortages, haphazard industrial and commercial improvement along transportation corridors have greatly increased the problems of urban development. The hydrologic changes in these water bodies were mainly on account of port extension, large scale land reclamation, construction of dams on the rivers that discharge into the backwaters and diversion of water flows by the construction of spillways, etc. For a long period there were no pollution control regulations and the untreated effluents including those from heavily polluting industries were being discharged into the backwaters. Geochemical studies of sediment core profiles describe the degree of contamination by encapsulating various amounts of biogenic compounds (including biogenic alkanes, sterols, carbohydrates, protein, hydrocarbons, etc.) and provide furthermore useful information on the changes in the quality of the sediments from past period (Faganelli et al. 1987; Holm 1988; Karbassi and Shankar 2005; Al-Juboury 2009; Ahmad et al. 2010; Chibunda et al. 2010). The present investigation also infers the quality of the biogeochemical constituents in the core sediments of the Cochin estuary which would strengthen the environmental dynamics of the studied site.

\section{Study area}

The study area was divided into three zones, viz., south, middle, and north (figure 1).

\subsection{South zone}

The zone originated from the southern bough of the fresh water river Moovattupuzha. One sediment core $\left(\mathrm{SS}_{1}\right)$ was taken from this zone which is far from industrial effluents.

\subsection{Middle zone}

This zone was considered as two segments and the first site $\left(\mathrm{MS}_{1}\right)$ is well regulated by a bund (namely Thannirmukham) which was constructed in order to prevent the intrusion of salt water into the paddy fields. The bund remains open during the monsoon season.

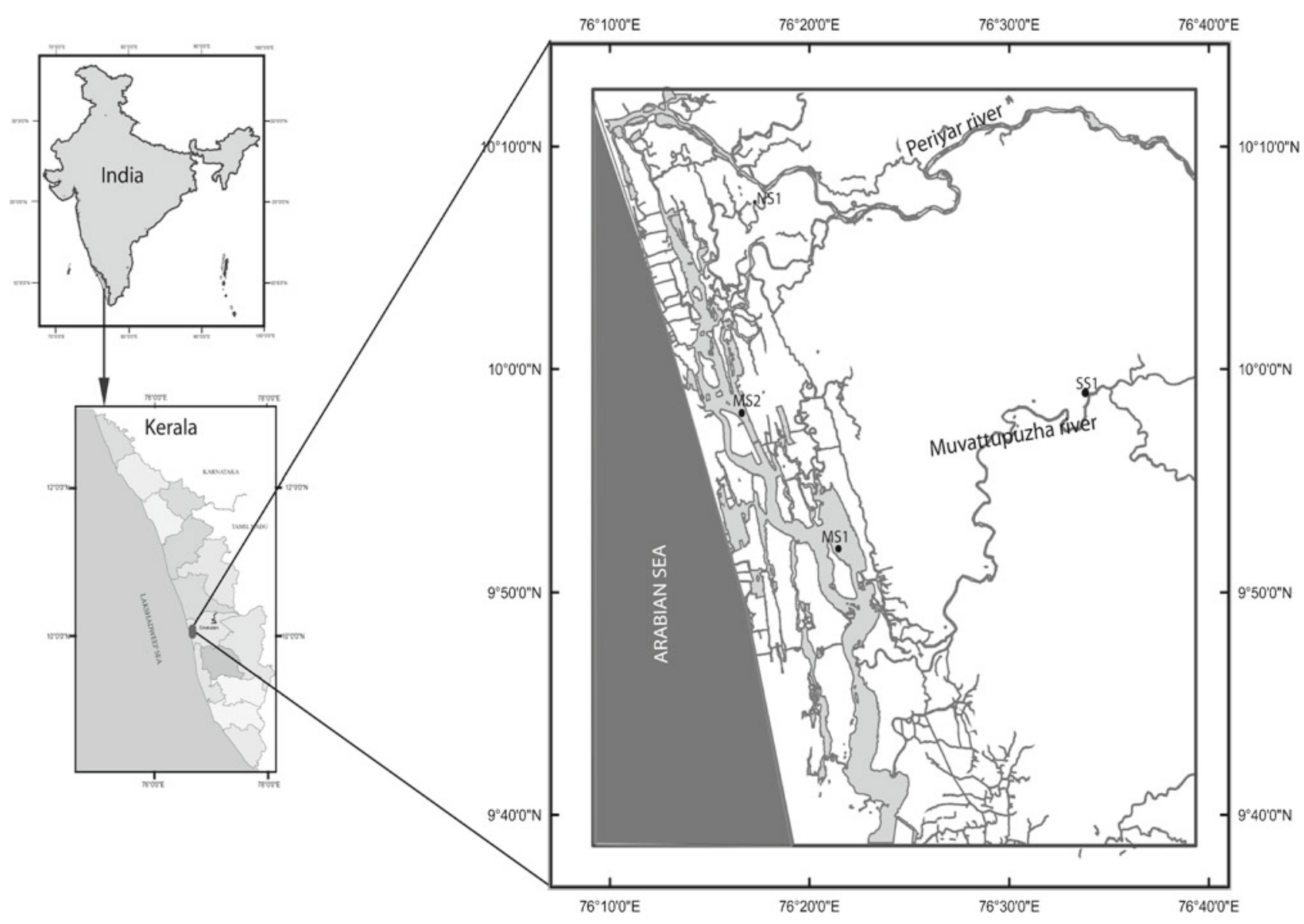

Figure 1. Location map of the study area. 
The second site $\left(\mathrm{MS}_{2}\right)$ was at Vallarpadam. With the advent of ICTT project, this area has become the backbone of the economy of Kerala State. It focuses on the enhancement of containerization in India, resulting in the improvement of trade and economic growth. Widespread activities like dredging and piling, along with anthropogenic inputs are carried out frequently. This zone has a perennial connection with the Arabian Sea and experiences an irregular encroachment of saline water intrusion thereby making cradle grounds for diverse types of flora and fauna.

\subsection{North zone}

This zone instigate from the industrial locale of Periyar - the life line of Kerala. One sediment core $\left(\mathrm{NS}_{1}\right)$ sample was collected from this zone. Large scale industries on the river bank discharge effluents directly into these waterways resulting in the accumulation of varying amounts of nutrients in the Periyar River.

\section{Sampling and methods}

The cores were collected at low tide by pushing a hand-held PVC core $(150 \mathrm{~cm}$ long with a diameter of $6.3 \mathrm{~cm}$ ) in November 2009 by a diver at the above-mentioned three zones of the CES, in varying depths $(1-3.50 \mathrm{~m})$ of the water body. The different length of the core obtained were $45 \mathrm{~cm}$ $\left(\mathrm{SS}_{1}\right), 55 \mathrm{~cm}\left(\mathrm{MS}_{1}\right), 63 \mathrm{~cm}\left(\mathrm{MS}_{2}\right)$ and $23 \mathrm{~cm}\left(\mathrm{NS}_{1}\right)$. The sediment cores were sliced into $3 \mathrm{~cm}$ segments, transferred to plastic vessels and each subsample constitutes $15,19,21$ and 10 for $\mathrm{SS}_{1}, \mathrm{MS}_{1}$, $\mathrm{MS}_{2}$ and $\mathrm{NS}_{1}$ cores, respectively. The $\mathrm{pH}$ (Thermo Orion $420 \mathrm{~A}+$ model) of the subsamples was immediately measured and then they were frozen at $4^{\circ} \mathrm{C}$ for further analysis. These subsamples were air dried, finely powdered and used for further chemical analysis.

The sediment samples were mixed and subjected for the analysis of tannin and lignin, lipid, carbohydrate and protein. Textural characteristics (sand, silt, and clay) and quantification of OM (protein, lipid and carbohydrate) were carried out by standard procedure. Texture was determined using pipette analysis (Lewis 1984). Total Organic Carbon (TOC) was processed by treating the samples with $1 \mathrm{M} \mathrm{HCl}$ to remove the carbonates and repeated two/three times in order to ensure the complete exclusion of carbonates. Samples were washed with Milli-Q water to remove salts and finally freeze dried. Organic carbon was determined using TOC analyzer (Elementar Vario Select, Germany). Samples were run with blank cups in order to correct the carbon associated with the tin cups. Standard sediments supplied by Elementar Vario Select, Germany, were used for calibration in the TOC analyzer. The detection limit for $\mathrm{OC}$ is $0.06 \%$. Total proteins were determined using the method of Lowry et al. (1951). Carbohydrate estimation was done by Phenol-Sulphuric acid method (Dubois et al. 1956). Tannin and lignin were batch-extracted from the sediments with $0.05 \mathrm{M} \mathrm{NaOH}$ solution for 90 minutes and filtered. To $5 \mathrm{ml}$ aliquots of filtrates, $1 \mathrm{ml}$ of citrate solution was added followed by $1 \mathrm{ml}$ folin reagent and $10 \mathrm{ml}$ carbonate tartarate reagent and kept it for 30 minutes. The optical density was measured at $765 \mathrm{~nm}$ (APHA 1995; Jose et al. 2008). Total lipid was estimated by the Sulphophosphovanillin method (Barnes and Blackstock 1973). All the analyses were carried out in triplicate and the average was reported. Protein, carbohydrate and lipid concentrations were converted to carbon equivalents by using the following conversion factors: $0.49,0.40$ and $0.75 \mathrm{~g}$ of $\mathrm{C} / \mathrm{g}$ respectively (Fabiano and Danovaro 1994). The sum total of protein, carbohydrate and lipid carbon were referred to as biopolymeric carbon (BPC) (Fichez 1991; Fabiano et al. 1995) and the study accounted accordingly. Sediment samples for the pigment analysis were immediately collected in $15 \mathrm{~cm}$ plastic vials for preservation by direct freeze drying. For the analysis of sedimentary chlorophyll and their degradation products, $0.5 \mathrm{~g}$ of freeze-dried sample was added to the glass centrifuge tube with $90 \%$ acetone and the mixture was sonicated at 5 atm for $30 \mathrm{sec}$ to disrupt the cells and kept in dark at $4^{\circ} \mathrm{C}$ for nearly $5 \mathrm{hrs}$ in order to ensure the complete extraction of the pigment. The mixture was then centrifuged at $3000 \mathrm{rpm}$ to separate the pigment solvent complex from the remaining sediment. This process was repeated until the colour of the extract was clear. The supernatant liquid was then transferred to UV spectrometer (GENESYS 10 UV Thermo spectra) for further analysis. The concentrations of chlorophyll, pheophytin and carotenoid pigments were measured by the spectrophotometric method (Parsons et al. 1984; APHA 1995; Aneeshkumar and Sujatha 2012). All the four core sediment standard deviation varied for lipid, tannin and lignin, carbohydrate, pigment and texture as $2.1-5.6 ; 0.1-0.6 ; 0.4-10.4 ; 0.2-1.9 ; 0.1-30.4$ and 5.7-31.3, respectively. Elemental compositions, CHNS of the samples were determined using Vario EL 111 CHNS Analyzer. The Principal Component Analysis (PCA) method, which enables a reduction in data and description of a given multidimensional system by means of small number of new variables, has been applied to the data. The data processing was carried out using the software Statistica 6.0. 


\section{Results}

\subsection{Sediment characteristics}

Colour, pH and texture for each core sediment are discussed.

\subsubsection{Core $S S_{1}$}

Varying colour combination in core sediment was observed. Up to $10 \mathrm{~cm}$ it showed blackish brown, brownish black till $40 \mathrm{~cm}$ and then blackish brown. Values of $\mathrm{pH}$ ranged from 5.4 at $3 \mathrm{~cm}$ depth to 7.2 at $42 \mathrm{~cm}$ depth and it was found to exhibit an increasing trend with minor fluctuations from surface to bottom. Clay content dominated in this core and showed a variation ranging from $3.2 \%$ to $97.8 \%$. Along the core, as depth increased clay fraction also increased.

\subsubsection{Core $M S_{1}$}

The whole core appeared blackish brown in colour. Values of $\mathrm{pH}$ ranged from 7 to 8 . Sand content dominated in this core. Relative textural distribution was in the order; sand $>$ clay $>$ slit.

\subsubsection{Core $M S_{2}$}

Mixed black and grey colour at $0-36 \mathrm{~cm}$ and uniform black colour up to $63 \mathrm{~cm}$ were noted. Values of $\mathrm{pH}$ ranged from 7.9 at $63 \mathrm{~cm}$ depth to 8.7 at $9 \mathrm{~cm}$ depth and it exhibited a decreasing trend with minor fluctuations from surface to bottom. Sand content was intensified in this core. The textural variation was in the order; sand $>$ clay $>$ slit.

\subsubsection{Core $N S_{1}$}

The entire core were blackish brown in colour. Values of $\mathrm{pH}$ ranged from 6.1 to 6.6. The highest $\mathrm{pH}$ at $6 \mathrm{~cm}$ depth and lowest at $21 \mathrm{~cm}$ depth. Clay content varied between $1.9 \%$ and $85.4 \%$. Along the core as depth increased sand content also intensified.

\section{Organic matter (OM)}

The distribution and variation of $\mathrm{OM}$ in different core sediments are illustrated as follows.

\subsection{Core $S S_{1}$}

Percentage of TOC ranged from 2.7 to 3.8 , showing the lowest and the highest at a depth of $27 \mathrm{~cm}$ and $12 \mathrm{~cm}$, respectively. Total carbohydrate concentration ranged from 4.7 to $11.7 \mathrm{mg} / \mathrm{g}$. Maximum and minimum concentrations were observed at $6,18 \mathrm{~cm}$ depths, respectively. Towards the lower end of the core, concentration of carbohydrate was found increased. Concentration of total protein ranged from 0.9 to $7.1 \mathrm{mg} / \mathrm{g}$ and concentration of protein was fairly high at middle portions. The maximum was observed at a depth of $6 \mathrm{~cm}$ and minimum was at $39 \mathrm{~cm}$. Concentration of lipid was prime at the top portions and lowest towards bottom. At $39 \mathrm{~cm}$ depth the concentration reached maximum $(34.1 \mathrm{mg} / \mathrm{g})$ and again decreased to $15.1 \mathrm{mg} / \mathrm{g}$ at $45 \mathrm{~cm}$. Concentration of tannin and lignin ranged from 1.0 to $1.6 \mathrm{mg} / \mathrm{g}$. The highest was noted at $39 \mathrm{~cm}$ depth and the lowest at $18 \mathrm{~cm}$ depth. Relative OM distribution was in the order: lipid $>$ carbohydrate $>$ protein $>$ tannin and lignin (figure 2).

\subsection{Core $M S_{1}$}

TOC decreased from top $(0.7 \%)$ to bottom $(0.6 \%)$ of the core. Total carbohydrate concentration ranged from 0.7 to $9.1 \mathrm{mg} / \mathrm{g}$. The lowest concentration was observed at the depth, $24 \mathrm{~cm}$ and the highest at $39 \mathrm{~cm}$. Concentration of carbohydrate was enriched at the bottom of the core. Concentration of total protein ranged from 0.2 to $1.6 \mathrm{mg} / \mathrm{g}$ at 3 and $24 \mathrm{~cm}$ depth, respectively. Concentration of protein was the maximum at the middle portion and almost constant towards the bottom. Total lipid concentration ranged from 1.3 to $9.1 \mathrm{mg} / \mathrm{g}$ and lowest at $45 \mathrm{~cm}$ depth and the highest at $39 \mathrm{~cm}$ depth. Concentration of lipid was enriched from the surface to the middle portions of the core. The tannin and lignin concentration ranged from 0.09 to $0.46 \mathrm{mg} / \mathrm{g}$. The lowest concentration was observed at $3 \mathrm{~cm}$ depth and the highest at $54 \mathrm{~cm}$ depth. Concentration of tannin and lignin augmented towards the bottom of the core. Relative OM distribution was in the order; lipid $>$ carbohydrate $>$ protein $>$ tannin and lignin (figure 2).

\subsection{Core $M S_{2}$}

Percentage of TOC ranged from 0.7 to 1.2 . The maximum was noted at $24 \mathrm{~cm}$ depth and minimum at $6 \mathrm{~cm}$ of the core. TOC values increased towards the bottom of the core. Concentration of total carbohydrate ranged from 0.9 to $1.6 \mathrm{mg} / \mathrm{g}$. The lowest concentration was observed at $54 \mathrm{~cm}$ depth and the highest at $36 \mathrm{~cm}$ depth. Concentration of carbohydrate was enriched in the surface and middle portions of the core. Total protein concentration ranged from 0.2 to $0.8 \mathrm{mg} / \mathrm{g}$. The lowest concentration was observed at $6 \mathrm{~cm}$ depth and the highest at $29 \mathrm{~cm}$ depth of the core. Concentration of protein increased from the middle to the bottom 

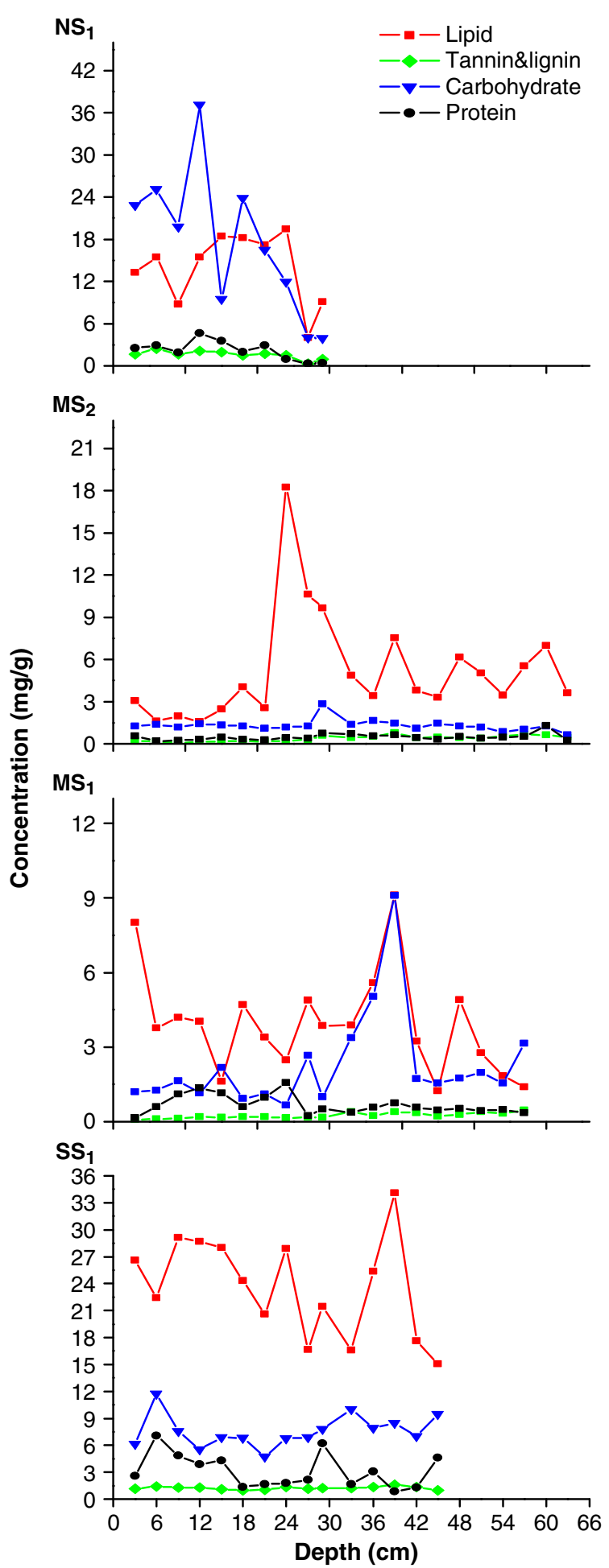

Figure 2. Distribution profile of organic matters $(\mathrm{mg} / \mathrm{g})$ in different cores.

portions of the core. Total lipid concentration ranged from 1.6 to $18.3 \mathrm{mg} / \mathrm{g}$. The lower concentration was observed at the depth of $12 \mathrm{~cm}$ and the higher at $21 \mathrm{~cm}$ depth. Lipid concentration was the highest in the middle portions of the core. Concentration of tannin and lignin ranged from 0.1 to $0.8 \mathrm{mg} / \mathrm{g}$. The lowest concentration was observed at $9 \mathrm{~cm}$ depth and the highest concentration was at $39 \mathrm{~cm}$ depth of the core. Concentrations of tannin and lignin were found increasing towards the bottom portions of the core. Relative OM distribution was in the order: lipid $>$ carbohydrate $>$ protein $>$ tannin and lignin (figure 2).

\subsection{Core $N S_{1}$}

Percentage of TOC ranged from 0.6 to 2.9. The maximum was noted at $12 \mathrm{~cm}$ depth and the minimum at $27 \mathrm{~cm}$ of the core. In this core the amount of all the OM were drove upon same manner. Concentration was the highest in middle portions and the lowest in bottom portions of the core. Concentration of the total carbohydrate ranged from 3.9 to $37.1 \mathrm{mg} / \mathrm{g}$. Concentration of total protein ranged from 0.3 to $4.6 \mathrm{mg} / \mathrm{g}$. Total lipid concentration ranged from 4.0 to $19.5 \mathrm{mg} / \mathrm{g}$ and finally the tannin and lignin content ranged from 0.3 to $2.4 \mathrm{mg} / \mathrm{g}$. The relative $\mathrm{OM}$ distribution was in the order: carbohydrate $>$ lipid $>$ protein $>$ tannin and lignin (figure 2).

\section{Discussion}

Estuaries are highly dynamic and influenced by strong tidal action, entangled with fresh water and coastal discharges. A number of investigations in recent years have shed light on the varied nature and character of estuarine and mangrove sediments in and around Cochin estuary (Geetha et al. 2008; Manju et al. 2008; Niffy Benny 2009; Deepulal et al. 2011; Aneeshkumar and Sujatha 2012). The present study deals with the first detailed research work on core sediment biogeochemistry in the specific zones of Cochin estuarine system. In sediments, a wide variety of organic carbon forms are present and they range from freshly deposited litter to highly decomposed forms such as humus. The quality of organic matter in sediments is critical to the partitioning and bioavailability of sediment associated contaminants. Influence of total organic matter (TOM) in sediments is important to assess the fate, transport, deposition and retention of various inorganic and organic constituents. The high organic carbon associations which coincided with the high clay contents in the southern and northern parts of the estuary is attributed to the enhanced adsorption of organic carbon onto the clay minerals in the low salinity regimes (figure 2a). Lipid is one of the major biochemical compound produced by living organisms and constitute an important fraction of dissolved and particulate OM (Skoog and Benner 1997; Borsheim et al. 1999; Burdige et al. 2000). Besides, they are consumed by microhetero- 
tops in both fresh water and marine ecosystems and contribute essentially to the bacterial production (Rich et al. 1996). Its concentrations have been associated with the most labile fraction of sedimentary organics and it is considered the best descriptor of meiofauna abundance and biomass, over enzymatically hydrolysable aminoacids or protein contents (Gremare et al. 1997; Fabiano et al. 1995; Gremare et al. 2002). Elevated levels of lipid concentration found at three cores $\left(\mathrm{SS}_{1}, \mathrm{MS}_{1}\right.$ and $\mathrm{MS}_{2}$ ) indicates the biological activity associated with the productive nature of the environment (figure 2). Prevalence of carbohydrate concentration in the northern zone $\left(\mathrm{NS}_{1}\right)$ could be attributed to the anthropogenic input and the death and decay of aquatic organisms and floating plants. In the present study, the carbon normalized value was suggestive of its terrestrial origin. Proteins are the most important nitrogen-bearing compound in most of the organisms. The study revealed that concentration of protein accounted was fairly high at $\mathrm{SS}_{1}$ core and maximum at $6 \mathrm{~cm}$ depth $(7.1 \mathrm{mg} / \mathrm{g})$. Both carbohydrates and protein serve as structural and storage components and comprise of up to $40 \%$ of the $\mathrm{OM}$ in the marine niche and $75 \%$ of the OM in terrestrial organisms (Aspinall 1983; Parsons et al. 1984; Biersmith and Benner 1998). Tannins and lignins are high molecular weight polycyclic aromatic compounds which are widely distributed throughout the plant kingdom (Schnitzer and Khan 1972; Finar 1976; Field and Lettinga 1987). These compounds are highly resistant to biological degradation and have a great potential to damage the aquatic environment. The identification and quantification of these compounds in these marine environment infers the importance of land-derived organic detritus. Concentration of tannins and lignins was found higher at cores collected from the northern and southern regions, and it establishes the character of allochthonous origin. The weak flow and the huge input of industrial/agricultural waste in the northern and southern parts of the estuary result in high organic input in the study area. Decreasing trends of organic carbon detected in the middle zone may be due to strong rectilinear current, which maintains an effective flushing. Organic matter has significant relation with fine fraction of the sediment. In the top sections of the core concentration of protein, lipid and carbohydrate were found intensified in the northern $\left(\mathrm{NS}_{1}\right)$ and southern $\left(\mathrm{SS}_{1}\right)$ regions, and diminished in the core samples obtained from the middle zone $\left(\mathrm{MS}_{1}\right.$ and $\left.\mathrm{MS}_{2}\right)$. Mid-portions of the cores $\mathrm{NS}_{1}$, $\mathrm{MS}_{1}$ and $\mathrm{MS}_{2}$ were enriched with organic matters. In the southern zone $\left(\mathrm{SS}_{1}\right)$, concentration of these $\mathrm{OM}$ was deficient. Bottom sections of the cores showed decrease in the concentration of $\mathrm{OM}$ in the cores $\mathrm{NS}_{1}, \mathrm{MS}_{1}$ and $\mathrm{MS}_{2}$, whereas $\mathrm{SS}_{1}$ revealed a heavier input of these organic matters. These observations confirmed the dependence of texture on the modification of sediment OM.

For the past several years sedimentary plant pigments have been studied and proved to be a valuable indicator of paleoecology and so the pigment parameter was also included in the study. The concentration of pheophytin pigment subjugated in three cores $\left(\mathrm{MS}_{1}, \mathrm{MS}_{2}\right.$ and $\left.\mathrm{NS}_{1}\right)$ were highlighted (figure 3). The highest concentration $(96.3 \mathrm{mg} / \mathrm{kg})$ of pheophytin was observed in $\mathrm{NS}_{1}$ core at a depth of $6 \mathrm{~cm}$ and towards the bottom, concentration was below detectable level due to low adsorbing nature of the sandy sediment. In rest of the two cores, pheophytin content dominated in the bottom portions of the sediment core. According to Dell'Anno's et al. (2002), the predominance of pheopigments might be attributed to high turbidity, chemical contamination or other factors affecting photosynthetic potential of the primary producers. Generally carotenoids hold the largest potential for identifying the phototropic community contributing to the sediment record due to their taxonomical specificity and high stability in relation to other pigments. The higher concentration of carotenoid $(40.7 \mathrm{mg} / \mathrm{kg})$ detected (figure 3) in the fresh water augmented core, $\mathrm{SS}_{1}$ (at $36 \mathrm{~cm}$ depth) also confirmed the above concept (figure 2a).

Protein-carbohydrate ratio (PRT:CHO) is used as an index to evaluate the origin of material present in sediments and to determine the age of sedimentary organic matter (Cividanes et al. 2002). This ratio was generally higher in estuarine sediments which point to the presence of low dead organic matter accumulation, probably due to the vibrant condition of estuaries. In the present study this ratio showed an average value of $0.42,0.50,0.4$ and 0.1 in $\mathrm{SS}_{1}, \mathrm{MS}_{1}, \mathrm{MS}_{2}$ and $\mathrm{NS}_{1}$ cores, respectively. Even though the middle zone is subjected to strong hydrodynamic conditions, sediments from this region also showed less PRT:CHO value. This may be due to the influence of anthropogenic inputs and rapid development activities in and around the study area. Low protein-carbohydrate ratios suggest the presence of aged $\mathrm{OM}$ and the role of protein as a potentially limiting factor for benthic consumers. Less dynamic nature of waters in northern and southern parts of the study area also caused low protein-carbohydrate ratio. Earlier report suggests the dominance of carbohydrate and lower PRT:CHO ratio is a typical feature of detrital heterotrophic environments (Danovaro 1996). Lipid-carbohydrate ratio (LPD:CHO) showed an average value of $3.3,2.4,4.2$ and 1.1 in $\mathrm{SS}_{1}$, $\mathrm{MS}_{1}, \mathrm{MS}_{2}$ and $\mathrm{NS}_{1}$ cores, respectively, which in turn reflects energetic (food) quality of the organic 


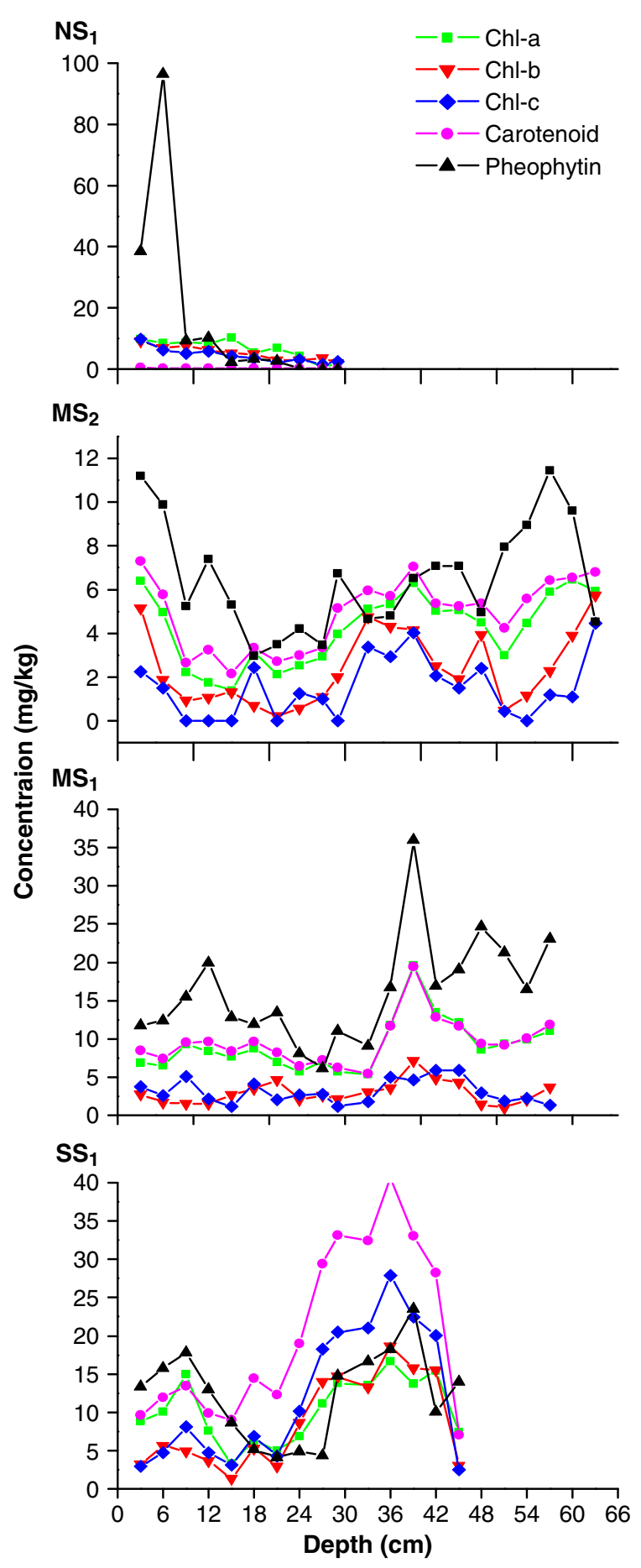

Figure 3. Variation pattern of pigments $(\mathrm{mg} / \mathrm{kg})$ in cores.

contents in the study area and well supports the earlier literatures (Gremare et al. 1997, 2002; Fabiano and Pusceddu 1998). Elevated value (15.758) was found in $\mathrm{MS}_{2}$ core at a depth of $21 \mathrm{~cm}$. Percent average of $\mathrm{BPC}$ was in the order $2.23,0.42,0.47$ and 1.9 in $\mathrm{SS}_{1}, \mathrm{MS}_{1}, \mathrm{MS}_{2}$ and $\mathrm{NS}_{1}$ cores, respectively. The correlation analysis of various biogeochemical parameters of sediment cores was shown in tables 1-4. In core $\mathrm{SS}_{1}$, biopolymeric carbon (BPC) showed a high significant correlation with

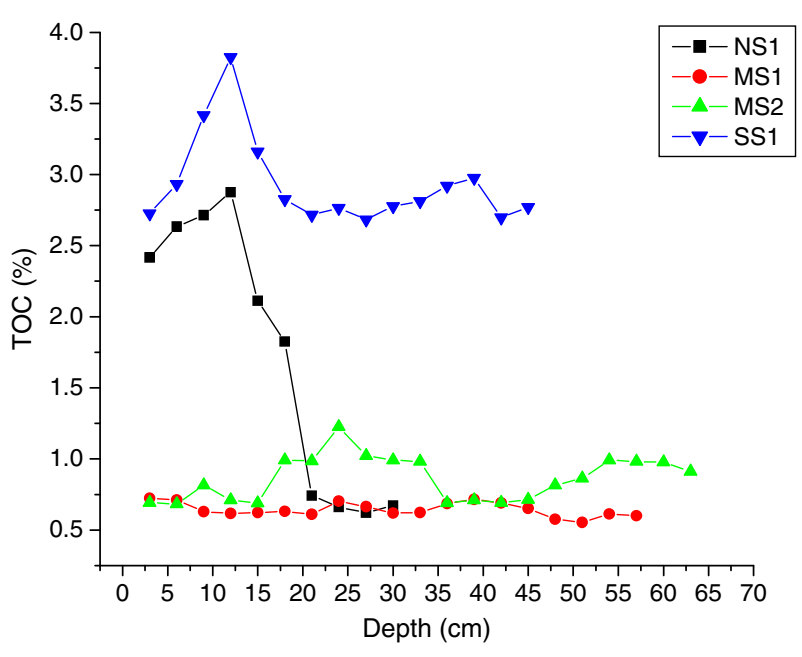

Figure 4. Distribution pattern of TOC (\%) in different cores.

lipid followed by tannin and lignin, and establishes them as the major contributors to BPC. A well momentous correlation of clay with chl$a$ and pheo pigments was also noticed. In core $\mathrm{MS}_{1}$, BPC had high significant correlation with lipid followed by carbohydrate. These observations suggest that lipid and carbohydrate also become a major contributor of BPC. A significant correlation of clay with carbohydrate, chl- $a$, chl- $b$, carotenoid and pheophytin was also observed. Generally carbohydrate has high affinity for the fine grained sediments, which constitute clay particles with increased surface area per unit weight for the absorption of OM. OM present in the sediments is found in the form of aggregates that are surrounded by clay particles. In core $\mathrm{MS}_{2}, \mathrm{BPC}$ exhibited a significant correlation with lipid. In core $\mathrm{NS}_{1}, \mathrm{BPC}$ had significant positive correlations with lipid, tannin and lignin, carbohydrate, protein and clay, indicating an equal contribution of all organic matter to BPC. A significant correlation was observed between BPC and clay. It was found that there is a positive correlation between the proportions of clay and $\mathrm{OM}$ in the aggregates and degradation of OM.

The ratio of TOC percentages to total sulfur (TS) percentages (TOC:TS) in sediments was determined. It ranges from $1.2-3.0$ for core $\mathrm{SS}_{1}$, 0.7-3.0 for $\mathrm{MS}_{1}, 0.465-1.226$ for $\mathrm{MS}_{2}$ and $1.2-$ 3.0 for $\mathrm{NS}_{1}$. Generally, under anoxic conditions dissolved sulfate is reduced to hydrogen sulfide gas, which reacts with iron minerals to form iron sulfides causing a qualitative redox status of the environment under deposition. Marine sediments undergoing sulfate reduction under euxinic/inhospitable bottom conditions typically have TOC:TS ratios lower than 1.5 (Niffy Benny 2009) and similar observation was found at core from 

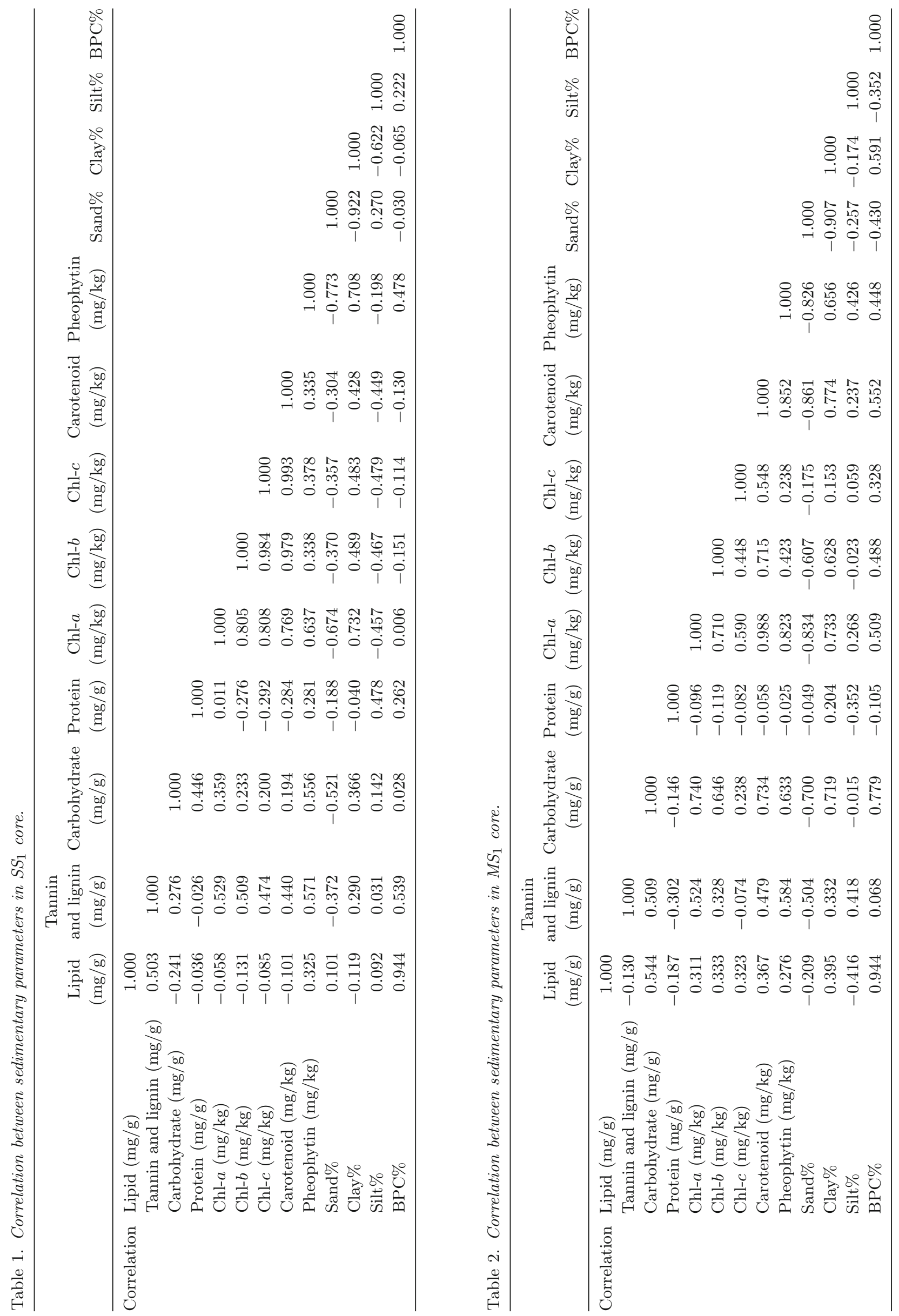

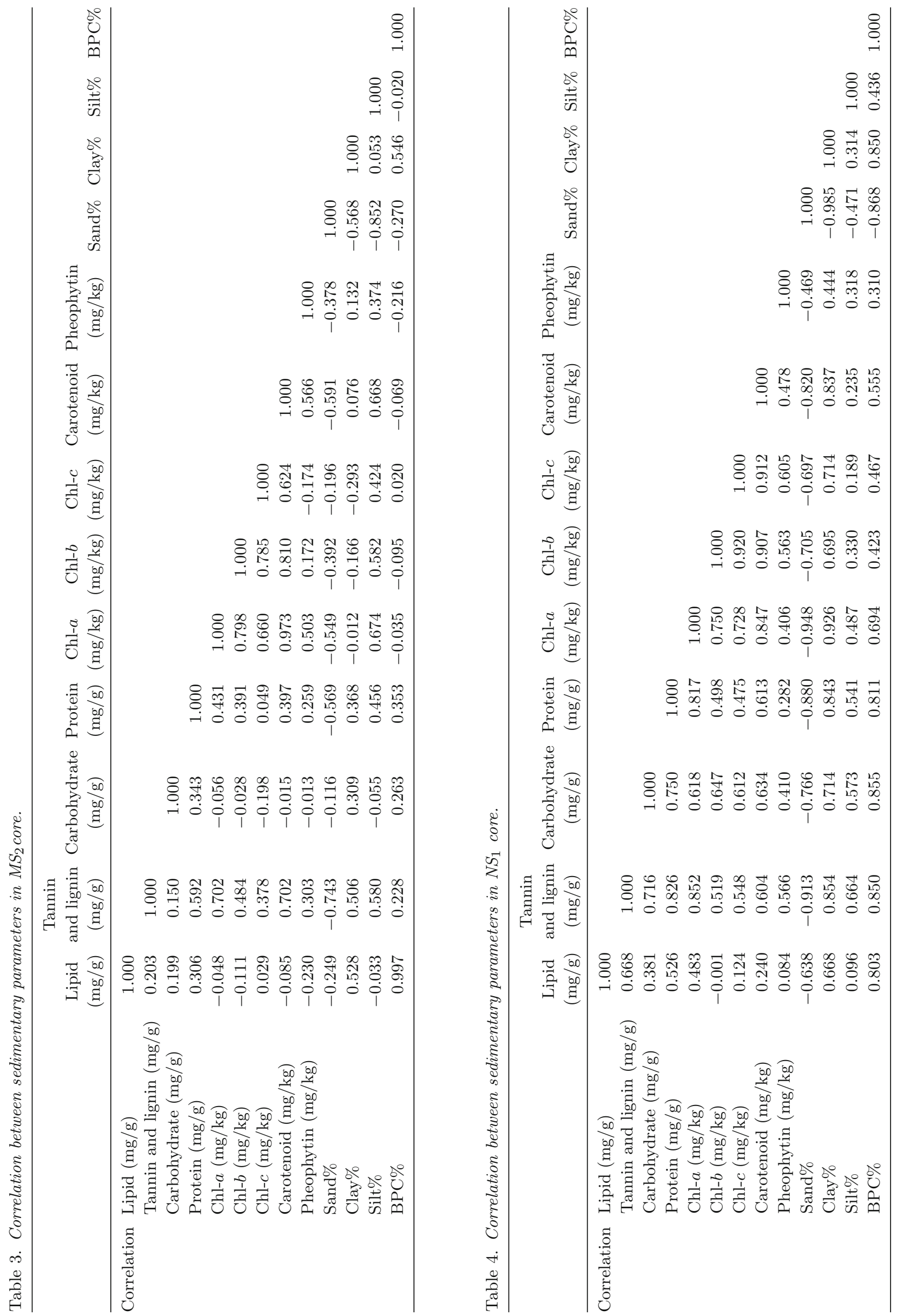
Table 5. Factor analysis matrix for core $S S_{1}$.

\begin{tabular}{lrrrr}
\hline & \multicolumn{4}{c}{ Component } \\
\cline { 2 - 5 } & \multicolumn{1}{c}{1} & \multicolumn{2}{c}{3} & \multicolumn{1}{c}{4} \\
\hline Component matrix $^{\mathrm{a}}$ & & & \\
Lipid (mg/g) & -0.018 & 0.708 & 0.670 & -0.187 \\
Tannin and lignin (mg/g) & 0.595 & 0.505 & 0.369 & 0.232 \\
Carbohydrate (mg/g) & 0.433 & 0.318 & -0.611 & 0.335 \\
Protein $(\mathrm{mg} / \mathrm{g})$ & -0.104 & 0.557 & -0.583 & 0.292 \\
Chl- $a(\mathrm{mg} / \mathrm{kg})$ & 0.932 & -0.007 & -0.040 & 0.048 \\
Chl- $b(\mathrm{mg} / \mathrm{kg})$ & 0.869 & -0.303 & 0.225 & 0.297 \\
Chl-c $(\mathrm{mg} / \mathrm{kg})$ & 0.869 & -0.290 & 0.260 & 0.268 \\
Carotenoid (mg/kg) & 0.835 & -0.312 & 0.266 & 0.316 \\
Pheophytin (mg/kg) & 0.716 & 0.588 & -0.168 & -0.182 \\
Sand\% & -0.734 & -0.248 & 0.465 & 0.304 \\
Clay\% & 0.809 & 0.022 & -0.310 & -0.484 \\
Silt\% & -0.527 & 0.447 & -0.168 & 0.587 \\
BPC\% & 0.033 & 0.879 & 0.433 & -0.064 \\
\hline
\end{tabular}

Extraction method: Principal Component Analysis.

${ }^{a}$ Four components extracted.

Table 6. Factor analysis matrix for core $M S_{1}$.

\begin{tabular}{lrrrr}
\hline & \multicolumn{4}{c}{ Component } \\
\cline { 2 - 5 } & \multicolumn{1}{c}{1} & \multicolumn{1}{c}{3} & \multicolumn{1}{c}{4} \\
\hline Component matrix ${ }^{\mathrm{a}}$ & & & \\
Lipid (mg/g) & 0.507 & 0.726 & 0.316 & -0.182 \\
Tannin and lignin (mg/g) & 0.518 & -0.598 & 0.044 & -0.394 \\
Carbohydrate (mg/g) & 0.870 & 0.135 & 0.045 & -0.284 \\
Protein (mg/g) & -0.103 & 0.218 & -0.857 & 0.321 \\
Chl- (mg/kg) & 0.944 & -0.172 & 0.035 & 0.232 \\
Chl- $b$ (mg/kg) & 0.758 & 0.086 & 0.062 & 0.165 \\
Chl-c (mg/kg) & 0.446 & 0.169 & 0.392 & 0.754 \\
Carotenoid (mg/kg) & 0.958 & -0.123 & -0.011 & 0.207 \\
Pheophytin (mg/kg) & 0.837 & -0.317 & -0.096 & -0.047 \\
Sand\% & -0.881 & 0.225 & 0.307 & 0.049 \\
Clay\% & 0.842 & 0.145 & -0.433 & -0.096 \\
Silt\% & 0.127 & -0.858 & 0.275 & 0.105 \\
BPC\% & 0.706 & 0.619 & 0.177 & -0.215 \\
\hline
\end{tabular}

Extraction method: Principal Component Analysis.

${ }^{\text {a}}$ Four components extracted.

middle zone $\left(\mathrm{MS}_{2}\right)$. These sites were under the threat of anthropogenic inputs and were associated with dredging and piling activities. These sediments also undergo sulfate reduction below an oxygenated water column exhibiting TOC:TS ratios in the range 1.5 to 5 and well corroborated earlier by Berner and Raiswell (1983). Sediments in the stations $\left(\mathrm{SS}_{1}, \mathrm{MS}_{1}\right.$ and $\left.\mathrm{NS}_{1}\right)$ were characterized under predominantly anoxic stipulation. Increased anoxia in the study area not only increases preservation of the pigments but also excludes the benthic animal community, thereby reducing ingestion and bioturbation, which has significant effect on the degradation of sedimentary pigments.
$\mathrm{C} / \mathrm{N}$ ratios are often used to differentiate marine from terrestrial organic matter (Redfield et al. 1963; Atkinson and Smith 1983; Perdue and Koprivnjak 2007), although selective degradation of different minerals in sediments can affect the $\mathrm{C} / \mathrm{N}$ ratios of organic matter (Muller 1997). Organic matter should have a $\mathrm{C} / \mathrm{N}$ ratio lower than 17 in order to be of nutritional use to invertebrates (Russel Hunter 1970). In this research findings, $\mathrm{C} / \mathrm{N}$ ratio varied from 18.5 to 25.23 , averaging 22.75 for core $\mathrm{SS}_{1}$; from 11.9 to 14.2 , averaging 12.9 for core $\mathrm{MS}_{1}$; from 20 to 22, averaging 21 for core $\mathrm{MS}_{2}$ and from 14.4 to 32.8, averaging 20.7 for core $\mathrm{NS}_{1}$. Among the four cores, $\mathrm{C} / \mathrm{N}$ ratio 
Table 7. Factor analysis matrix for core $M S_{2}$.

\begin{tabular}{|c|c|c|c|}
\hline & & omponent & \\
\hline & 1 & 2 & 3 \\
\hline Component matrix $^{\mathrm{a}}$ & & & \\
\hline Lipid (mg/g) & 0.126 & 0.835 & 0.432 \\
\hline Tannin and lignin $(\mathrm{mg} / \mathrm{g})$ & 0.843 & 0.230 & -0.062 \\
\hline Carbohydrate (mg/g) & 0.077 & 0.466 & -0.173 \\
\hline Protein $(\mathrm{mg} / \mathrm{g})$ & 0.633 & 0.404 & -0.138 \\
\hline Chl- $a(\mathrm{mg} / \mathrm{kg})$ & 0.909 & -0.280 & 0.065 \\
\hline Chl- $b(\mathrm{mg} / \mathrm{kg})$ & 0.773 & -0.374 & 0.325 \\
\hline Chl-c (mg/kg) & 0.566 & -0.382 & 0.695 \\
\hline Carotenoid (mg/kg) & 0.917 & -0.271 & -0.017 \\
\hline Pheophytin (mg/kg) & 0.463 & -0.157 & -0.702 \\
\hline Sand\% & -0.814 & -0.311 & 0.218 \\
\hline Clay\% & 0.267 & 0.789 & -0.268 \\
\hline Silt\% & 0.818 & -0.124 & -0.094 \\
\hline $\mathrm{BPC} \%$ & 0.150 & 0.855 & 0.407 \\
\hline
\end{tabular}

Extraction method: Principal Component Analysis.

a Three components extracted.

Table 8. Factor analysis matrix for core $N S_{1}$.

\begin{tabular}{lrrr}
\hline & \multicolumn{3}{c}{ Component } \\
\cline { 2 - 4 } & 1 & \multicolumn{1}{c}{3} \\
\hline Component matrix $^{\mathrm{a}}$ & & & \\
Lipid (mg/g) & 0.554 & -0.694 & -0.357 \\
Tannin and lignin (mg/g) & 0.915 & -0.250 & 0.184 \\
Carbohydrate (mg/g) & 0.833 & -0.050 & 0.222 \\
Protein (mg/g) & 0.862 & -0.268 & 0.086 \\
Chl-a (mg/kg) & 0.929 & 0.042 & -0.075 \\
Chl-b (mg/kg) & 0.771 & 0.596 & -0.015 \\
Chl-c (mg/kg) & 0.774 & 0.558 & -0.172 \\
Carotenoid (mg/kg) & 0.848 & 0.413 & 0.236 \\
Pheophytin (mg/kg) & 0.550 & 0.399 & 0.246 \\
Sand\% & -0.984 & 0.101 & 0.089 \\
Clay\% & 0.958 & -0.081 & -0.250 \\
Silt\% & 0.525 & -0.139 & 0.801 \\
BPC\% & 0.860 & -0.423 & -0.052 \\
\hline
\end{tabular}

Extraction method: Principal Component Analysis.

a Three components extracted.

was greater than 20 in three cores $\left(\mathrm{SS}_{1}, \mathrm{MS}_{2}\right.$, and $\mathrm{NS}_{1}$ ) ascertaining the input of terrestrial material into the area, justifying that the source of organic matter is allochthonous. From middle zone (core $\mathrm{MS}_{1}$ ), the ratio points out autochthonous character of the sediment. However, the succession of postdepositional changes may also modify the environment niche drastically. Percentage of elemental distributions (CHNS) in all the four sediment cores were in the order: $\mathrm{C}>\mathrm{S}>\mathrm{H}>\mathrm{N}$.

To confirm different variable associations, and identification of parameters controlling the organic matter distribution, factor analysis was carried out (tables 5-8). Varimax orthogonal rotation was employed to transform the analysis matrix and to limit the number of variables loaded in each factor (Buckley et al. 1995). In core $\mathrm{SS}_{1}$, four factors account for $71.3 \%$ of the total variance. The first factor accounted for high positive loadings on all the sedimentary parameters except sand, slit and lipid. Factor-2 exibit significant positive loadings for all $\mathrm{OM}$ and BPC. This clearly shows that high negative loading has occurred for all pigments and sand. Factor-3 showed significant positive loading for lipid and high negative loadings for carbohydrate, protein, pigments, clay and slit. Thus it is well established that the third component has undergone geochemical processes rather 
than diagenesis, which includes siltation and sorption/desorption. Factor-4 shows no such significant positive loadings. In $\mathrm{MS}_{1}$ core, four factors account for $84.5 \%$ of the total variance. The first factor shows positive loadings of all sedimentary parameters except for sand and protein, evidence to high significant loadings of pigments. Hence, this can be called the 'pigment controlled factor'. High positive loadings of lipid and BPC are the features of factor-2. No such high positive loadings to the sedimentary parameters were found in factor-3, but factor- 4 shows significant positive loadings to chlc. In $\mathrm{MS}_{2}$ core, three factors account for $71.1 \%$ of the total variance. The first factor shows positive loadings of all sedimentary parameters except sand and resulting in significant loadings of pigments, and profoundly it could be called the "pigment controlled factor'. Factor-2 shows high positive loadings on lipid, clay and BPC. But factor-3 shows no such high positive loadings. In core $\mathrm{NS}_{1}$, three factors account for $69.1 \%$ of the total variance. The same trend as in the core $\mathrm{MS}_{2}$ was observed in the first factor. Though factor- 2 shows no such high positive loadings, the factor-3 showed high positive loading to slit. Thus from factor analysis it is inferred that 'organic matter controlled factor', has a maximum amount of total variance in all the four core sediments, indicating good correlation of $\mathrm{OM}$ in most of the variables studied. However, combining the sedimentary record with other biological and geochemical indicators in multi-proxy studies still constitutes the most robust method for interpreting long term changes in ecosystem structure.

\section{Conclusion}

The present study has been the first comprehensive attempt ever made to characterize the core sediment biogeoorganics in the CES. It has served to emphasis the prominent role of biogeoorganics in regulating the complex interactive forces that operate within the estuarine system and also provides a baseline data for future research on anthropogenic impacts in the region. Characterization of organic matter has made it possible to trace the source and predict the fate of allochthonous and autochthonous inputs that find their way into this transition zone. Among the four sediment cores, percentage of TOC was higher at $\mathrm{SS}_{1}$ and $\mathrm{NS}_{1}$ coinciding with high clay contents in the southern and northern parts of the estuary. This is attributed to the enhanced adsorption of organic carbon onto the clay minerals in the low salinity regimes. Their relative organic matter distributions in the three cores except $\mathrm{NS}_{1}$ core were in the order: lipid $>$ carbohydrate $>$ protein $>$ tannin and lignin. Dominance of carbohydrates over lipids and proteins in the northern zone indicated lower nutritive aspect of the organic matter, and their aged and refractory nature. TOC/TS ratio indicates the anoxic behaviour of all the core sediments. $\mathrm{C} / \mathrm{N}$ ratio supports the allochthonous character of the three sediment cores $\left(\mathrm{SS}_{1}, \mathrm{NS}_{1}\right.$, $\mathrm{MS}_{2}$ ). Concentration of pheophytin pigment was found subjugated in three cores $\left(\mathrm{MS}_{1}, \mathrm{MS}_{2}\right.$ and $\mathrm{NS}_{1}$ ) indicating the long term diagenesis. Increased anoxia in the study area not only increases preservation of pigments, but also excludes the benthic animal community, thereby reducing ingestion and bioturbation, which have a significant effect on the degradation of sedimentary pigments.

\section{Acknowledgements}

The authors wish to acknowledge Ministry of Earth Sciences (MoES) under SIBER-GEOTRACES programme, Government of India, for the financial support to carry out the research work. They thank the Head, Department of Chemical Oceanography, CUSAT for providing laboratory facilities and suggestions. The authors express their heartfelt thanks for the scientific encouragement given by the Associate Editor and two anonymous reviewers. The authors extend their thanks to Ms. Geetha Dinesh for preparing the images.

\section{References}

Ahmad M K, Islam S, Rahman S, Haque M R and Islam M M 2010 Heavy metals in water, sediment and some fishes of Buriganga River, Bangladesh; Int. J. Environ. Res. 4(2) 321-332.

Al-Juboury A I 2009 Natural pollution by some heavy metals in the Tigris River, northern Iraq; Int. J. Environ. Res. 3(2) 189-198.

Alongi D M 1998 Coastal Ecosystem Processes; CRC Press, New York.

Aneeshkumar N and Sujatha C H 2012 Biomarker pigment signatures in Cochin back water system - a tropical estuary, southwest coast of India; Estuarine Coast. Shelf Sci. 99 182-190.

APHA 1995 Standard methods for the examination of water and waste water, American Public Health Association, 19th edn, Washington.

Aspinall G O 1983 The polysaccharides, Vol. 2, Academic Press, New York.

Atkinson M J and Smith S V 1983 C:N:P ratios of benthic marine plants; Limnol. Oceanogr. 28 568-574.

Barnes H and Blackstock J 1973 Estimation of lipids in marine animals tissues: Detailed investigation of the sulphophosphovanillin method for total lipids; J. Expt. Mar. Biol. Ecol. 12 103-118.

Berner R and Raiswell R 1983 C/S method for distinguishing fresh water from marine sedimentary rocks; Geology $\mathbf{1 2}$ $365-368$.

Bianchi T S, Pennock J R and Twilley R R 1999a Biogeochemistry of Gulf of Mexico estuaries: Implications 
for management; In: Biogeochemistry of Gulf of Mexico Estuaries, John Wiley, New York, pp. 407-421.

Biersmith A and Benner R 1998 Carbohydrates in phytoplankton and freshly produced dissolved organic matter; Mar. Chem. 63 131-144.

Borsheim K Y, Myklestael S M and Sneil J A 1999 Monthly profiles of DOC, mono and polysaccharides at two locations in the Trondheims fjord (Norway) during two years; Mar. Chem. 63 255-272.

Buckley D E, Smith J N and Winters G V 1995 Accumulation of contaminant metals in marine sediments of Halifax Harbour, Nova Scotia: Environmental factors and historical trends; Appl. Geochem. 10(2) 175-195.

Burdige D J, Skoog A and Gardener K G 2000 Dissolved and particulate carbohydrate in contrasting marine sediment; Geochim. Cosmochim. Acta 64 1029-1041.

Chibunda R T, Pereka A E, Phiri E C J and Tungaraza C 2010 Ecotoxicity of mercury contaminated sediment collected from Mabubi River (Geita district, Tanzania) to the early life stages of African Catfish (Clarias gariepinus); Int. J. Environ. Res. 4(1) 49-56.

Cividanes S, Incera M and Lopez J 2002 Temporal variability in the biochemical composition of sedimentary organic matter in an intertidal flat of the Galician coast (NW Spain) ocean; Acta 25 1-12.

Danovaro R 1996 Detritus-bacteria-meofauna interactions in a seagrass bed (Posidonia Oceanica) of the NW Mediterraneon; Mar. Biol. 127 1-13.

Deepulal P M, Gireesh Kumar T R, Sujatha C H and Rejomon George 2011 Chemometric study on the trace metal accumulation in the sediments of the Cochin Estuary - Southwest coast of India; Environ. Monit. Assess., November 2011

Dell'Anno A, Pusceddu A and Danovaro R 2002 Assessing the trophic state and eutrophication of coastal marine systems - a new approach based on the biochemical composition of sediment organic matter; Mar. Pollut. Bull. 44 611-622.

Dubois M, Gilles K A, Hamilton J K, Reebers P A and Smith F 1956 Colorimetric method for the determination of sugars related compounds; Anal. Chem. 28 350-355.

Fabiano M and Danovaro R 1994 Composition of organic matter in sediments facing a river estuary (Tyrrhenian Sea): Relationships with bacteria and microphytobenthic biomass; Hydrobiologia 277 71-84.

Fabiano M, Danovaro R and Fraschetti S 1995 Temporal trend analysis of the elemental composition of the sediment organic matter in subtidal sandy sediments of the Ligurian Sea (NW Mediterranean): A three years study; Cont. Shelf Res. 15 1453-1469.

Fabiano M and Pusceddu A 1998 Total hydrolysable particulate organic matter (carbohydrates, proteins and lipids) at a coastal station in terra Nova Bay (Ross Sea, Antarctica), Polar Biol. 19 125-132.

Faganelli J, Ogorole B, Misic M, Dollenen T and Pezdic J 1987 Organic geochemistry of two $40 \mathrm{~m}$ sediment cores from the Gulf of Trieste Northern Adriatic; Coast. Shelf Sci. 25 157-167.

Fichez R 1991 Composition and fate of organic matter in submarine cave sediments: Implications for the biogeochemical cycle of organic carbon; Oceanologica Acta 14 369-377.

Field J A and Lettinga G 1987 The methanogenic toxicity and anaerobic degradability of a hydrolysable tannin; Water Res. 21 367-374.

Finar I L 1976 Organic Chemistry, Vol. 1, Longman, Singapore.
Geetha R, Chandramohanakumar N and Mathews L 2008 Geochemical reactivity of surficial and core sediment of a tropical mangrove ecosystem; Int. J. Environ. Res. 2(4) 329-342.

Gopalan U K, Doyil T, Vengayil P, Udaya V and Krishnankutty M 1983 The shrinking backwaters of Kerala; J. Mar. Biol. Assoc. India 25 131-141.

Gremare A, Mederach L, Debovee F, Amoroux J M, Vetion G and Albert P 2002 Relationships between sedimentary organics and benthic meiofauna on the continental shelf and the upper slope of the Gulf of Lions (NW Mediterranean); Mar. Ecol. Prog. Ser. 234 85-94.

Gremare J M, Amouroux, Charles F, Dinet A, Riaux-Gobin C, Baudart J, Medernach L, Bodiou J Y, Vetion G and Colomines J C 1997 Temporal changes in the biochemical composition and nutritional value of the particulate organic matter available to surface deposit feeders: A two-year study; Mar. Ecol. Prog. Ser. 150 195-206.

Hedges J I and Kiel R G 1995 Sedimentary organic matter preservation: An assessment and speculative synthesis; Mar. Chem. 49 81-115.

Hobbie J E (ed.) 2000 Estuarine science: The key to progress in coastal ecological research; In: Estuarine science: A synthetic approach to research and practice, Island Press, Washington DC, pp. 1-11.

Holm N G 1988 Arsenic regeneration from estuarine sediments of the Bothnian Bay, Weden; Chem. Geol. 68 89-98.

Howarth R W, Jaworski N, Swaney D, Townsend A and Billen G 2000 Some approaches for assessing human influences on fluxes of nitrogen and organic carbon to estuaries; In: Estuarine science: A synthetic approach to research and practice (ed.) Hobbie J E, Island Press, Washington DC, pp. 17-42.

Howarth R W, Sharpley A and Walker D 2002 Sources of nutrient pollution to coastal waters in the United States: Implications for achieving coastal water quality goals; Estuaries 25 656-676.

Jose A, Ake C and Vázquez G 2008 Phytoplankton variation and its relation to nutrients and allochthonous organic matter in a coastal lagoon on the Gulf of Mexico; Estuarine Coast. Shelf Sci. 78 705-714.

Karbassi A R and Shankar R 2005 Geochemistry of two sediment cores from the west coast of India; Int. J. Environ. Sci. Tech. 1(4) 307-316.

Lewis D W 1984 Practical sedimentology; Huchinson Ross Publishing Co., Stroudsburg, 229p.

Lowry O H, Rosebrough N J, Fart A L and Randall R J 1951 Protein measurement with Folin Phenol reagent; J. Biol. Chem. 193 265-275.

Manju Mary Joseph, Ratheesh Kumar C S, Gireesh Kumar T R, Renjith K R and Chandramohanakumar N 2008 Biogeochemistry of surfacial sediments in the intertidal systems of a tropical environment; Chem. Ecol. 24 $247-258$.

Menon N, Balachand N and Menon A N 2000 Hydrobiology of the Cochin backwater system - A review; Hydrobiologia $430149-183$.

Middelburg Jack J, Gerard K, Joop N, Annette W, Hass Wim De, Tom V, Jaco F W A and Van der N 1996 Organic matter mineralization in intertidal sediments along an estuarine gradient; Marine Ecol. Progr. Series 132 157-168.

Muller P J 1997 C/N ratios in Pacific deep sea sediments: Effect of inorganic ammonium and organic nitrogen compound sorbed by clays; Geochim. Cosmochim. Acta $\mathbf{4 1}$ $765-776$

Niffy Benny 2009 Unravelling a benchmark for sulphur akin in the Cochin Estuarine System; Ph.D Thesis, 
Cochin University of Science and Technology, Cochin, Kerala.

Parsons T R, Takahashi M and Hargrave B 1984 Biological Oceanographic Processes; 3rd edn, Pergamon Press, New York.

Perdue E M and Koprivnjak J F 2007 Using the C/N ratio to estimate terrigenous inputs of organic matter to aquatic environments; Estuarine Coast. Shelf Sci. $\mathbf{7 3}$ 65-72.

Redfield A C, Ketchum B H and Richards F A 1963 The influence of organisms on the composition of sea-water; In: In the Sea (ed.) Hill N, 2nd edn, Wiley, New York, pp. $26-77$.
Rich J H, Decklow H W and Kirchman D L 1996 Concentration and uptake of neutral monosaccharides along $140^{\circ} \mathrm{W}$ in the equatorial pacific: Contribution of glucose to heterotrophic bacterial activity and DOM flux; Limnol. Oceanogr. 41 595-604.

Russel Hunter W D 1970 Aquatic productivity: An introduction to some basic aspects of biological oceanography and limnology; Collier-Macmillan, London, 306p.

Schnitzer M and Khan S U 1972 Humic substances in the environment; Marcel Dekker, New York, 327p.

Skoog A and Benner R 1997 Dldose in various size fractions of marine organic matter: Implications for carbon cycling; Limnol. Oceanogr. 42(8) 1803-1813. 